\title{
OBITUARIES
}

\section{Sir John Marshall}

Sir John Marshall, Director General of Archæology in India from 1902 to 1931, died on 17th August, 1958 at the age of 82. After the deaths of his friends and colleagues Foucher and Vogel, he was the last surviving European scholar to have devoted his life to Indian art and archæology. We whom circumstances have made observers and critics rather than planners and doers cannot but envy him his good fortune as a pioneer. He was 26 when he left for India, and the following thirty-two years were marked by a tireless energy and devotion. It is extraordinary what he accomplished. The work of conservation alone entailed so much administration and paperwork that it is astonishing that he found time for his long series of excavations, his detailed and prompt reports, and his personal research.

The period up to the First World War was occupied with organization of the Archæological Department, conservation of Islamic monuments, and excavation and conservation on Buddhist sites in Gandhara and Bihar, of which perhaps Sarnath was the most important. In 1913 Marshall began work on Taxila, which occupied him off and on for twenty years. From 1922 to 1927 he excavated at Mohenjodaro ; the results, among the most fruitful in the archæological investigations of this century, were published in 1931 in three great volumes. The publication of his book on Taxila was unfortunately delayed by the Second World War and it did not appear until 1952. Marshall considered this his best work; it was certainly nearest his heart. But some may think Sanchi his finest monument. The stupas and temples on the lovely hill were restored with the greatest care and taste, and Marshall's publication on it (1940) in three volumes with the help of his friends Foucher and N. G. Majumdar remains the only definitive description of any great Indian historic site. Another perfect work is his "Monuments of Muslim India" in Volume III of the Cambridge History of India - a brilliant summary, which needs little revision even after a lapse of twenty years.

Marshall's work has often been compared with that of his great predecessor, Cunningham. Cunningham was indeed almost a genius and his intuition was remarkable, but he had not to engage in the vast 
administrative struggles of the twentieth century. Marshall took these in his stride, and, I think, none of our Indian colleagues, many of whom were his pupils, would deny that the Archæological Department is what it is to-day through the care and foresight of his early planning. Some have criticized his methods of excavation. Marshall was too philosophical and critical to think that any method had absolute validity or that any work of his was done once and for all. He was himself courteous and generous especially to younger men. Though aware that his achievement was no mean one, he shared his generation's distaste for " window dressing ".

Marshall devoted his life to India, and loved the country and its people. The Governments of India and Pakistan recognised his devotion by making it possible for him to continue his work in his retirement. The fruit of their wise generosity is his last book, "Buddhist Art in Gandhara," now in the press.

Douglas Barrett.

\section{Arshak Safrastian}

Arshak Safrastian, for many years a member of the Society, died on 25th September, 1958, at the age of seventy-two. A specialist in Armenian studies, he had in later years interested himself in Urartian and Hurrian themes. Much of his work appeared in Armenian language periodicals; but he was editor of the Armenian monthly Massis, published in London between the wars, and in that journal he provided in English many useful summaries of contemporary Armenian research. He wrote on "Armenian History" for the 14th edition of the Encyclopaedia Britannica and, in 1948, published a short book, Kurds and Kurdistan. His more scholarly work in English included a paper on "The Hurri-lands" in Georgica, 4/5 (1937) and " The Land of Hurri in the Armenian Language and Literature " read at the XXI International Congress of Orientalists in Paris in 1948. His magnum opus in English on the Hurri runs into several hundred pages of typescript and is the result of many years of research. It is hoped that this work may be published.

Arshak Safrastian was born in the ancient city of Van, of a large and patriarchal family engaged in farming and trade. Before the First World War he was H.B.M. Acting Vice-Consul in Bitlis. During 1915-16, he served in an Armenian unit of the Russian 